\title{
Growth and development of Conyza bonariensis based on days or thermal units
}

\author{
Daniel Jorge Soares(1), Wladecir Salles de Oliveira( ${ }^{(1)}$, Elvio Lorençato Uzuele(1), \\ Saul Jorge Pinto de Carvalho(2), Ramiro Fernando Lopez Ovejero ${ }^{(1)}$ and Pedro Jacob Christoffoleti( ${ }^{(3)}$
}

\begin{abstract}
${ }^{(1)}$ Monsanto do Brasil, Avenida Nações Unidas, no 12.901, Torre Norte, CEP 04578-910 São Paulo, SP, Brazil. E-mail: daniel.j.soares@monsanto.com, wsolivei@gmail.com, elvio.I.uzuele@monsanto.com, ramiro.f.ovejero@monsanto.com (2)Instituto Federal do Sul de Minas Gerais, Campus Machado, Rodovia Machado-Paraguaçu, Km 3, Santo Antônio, CEP 37750-000 Machado, MG, Brazil. E-mail: sjpcarvalho@yahoo.com.br ${ }^{(3)}$ Universidade de São Paulo, Escola Superior de Agricultura Luiz de Queiroz, Avenida Pádua Dias, № 11, Caixa Postal 09, CEP 13418-900 Piracicaba, SP, Brazil. E-mail: pjchrist@usp.br
\end{abstract}

\begin{abstract}
The objective of this work was to evaluate the growth and development of a glyphosateresistant population of Conyza bonariensis in different sowing dates (autumn, winter, and spring) and in two agricultural environments, based on days or thermal units. Five experiments were performed in two agricultural environments in Brazil: two in the municipality of Não-Me-Toque, in the state of Rio Grande do Sul - with sowings in July and September 2011; and three in the municipality of Santa Cruz das Palmeiras, in the state of São Paulo - with sowings in April, July, and September 2011. In each trial, ten evaluations of the phenological development and total dry mass of $C$. bonariensis were performed, fitting these variables to a unit of time in days or growing degree days. The phenological development of $C$. bonariensis had the best adjustment at the base temperature of $8.4^{\circ} \mathrm{C}$, and was affected by sowing date and agricultural environment. In autumn, with decreasing temperature and photoperiod, plants are still able to accumulate dry mass, but without floral induction. In spring, with increasing temperature and photoperiod, dry mass accumulation is lower, but phenological development is faster, with significant floral induction.
\end{abstract}

Index terms: hairy fleabane, dry mass, growing degree days, modeling, phenology, weed biology.

\section{Crescimento e desenvolvimento de Conyza bonariensis com base em dias ou unidades térmicas}

\begin{abstract}
Resumo - O objetivo deste trabalho foi avaliar o crescimento e o desenvolvimento de uma população de Conyza bonariensis resistente ao herbicida glifosato em diferentes datas de semeadura (outono, inverno e primavera) e dois ambientes agrícolas, com base em dias ou unidades térmicas. Foram desenvolvidos cinco experimentos em dois ambientes agrícolas: dois no Município de Não-Me-Toque, RS - com semeaduras em julho e setembro de 2011; e três no Município de Santa Cruz das Palmeiras, SP - com semeaduras em abril, julho e setembro de 2011. Em cada experimento, realizaram-se dez avaliações do desenvolvimento fenológico e do acúmulo de massa de matéria seca total de $C$. bonariensis, com ajuste das variáveis à contagem de tempo em dias ou graus-dia acumulados. O desenvolvimento fenológico da espécie apresentou melhor ajuste com temperatura basal de $8,4^{\circ} \mathrm{C}$, e foi influenciado pelo ambiente agrícola e pela data de semeadura. No outono, com temperatura e fotoperíodo decrescentes, as plantas permanecem aptas a acumular massa de matéria seca, porém sem indução floral. Na primavera, com temperatura e fotoperíodo crescentes, o acúmulo de massa de matéria seca é menor, mas o desenvolvimento fenológico é mais rápido, com indução floral significativa.
\end{abstract}

Termos para indexação: buva, massa de matéria seca, graus-dia acumulados, modelagem, fenologia, biologia das plantas daninhas.

\section{Introduction}

Plants of the Conyza genus have been considered weeds in more than 40 crops (Lazaroto et al., 2008), where they are popularly known as hairy fleabane or horseweed. These are highly prolific species, which can produce between 110 and 200 thousand viable seeds per plant (Lazaroto et al., 2008). Conyza species grow in acidic, sandy soils and tolerate water stress. Seeds are easily dispersed by wind due to modifications in their achenes, called "papus", which measure at least twice the size of seeds (Dauer et al., 2006; Lazaroto et al., 2008). One of these species, C. bonariensis, is native to South America, with few occurrences in Argentina, Brazil, Paraguay, and Uruguay. 
In Brazil, Conyza plants are more frequently found in the Southern, Southeastern, and Midwestern regions (Santos et al., 2013), where they have become one of the most important weeds, mostly due to their resistance to glyphosate (Moreira et al., 2007; Lamego \& Vidal, 2008; Moreira et al., 2010b) and, in some regions, to their multiple resistance to herbicides that inhibit 5-enolpyruvylshikimate-3-phosphate synthase (EPSPs) and acetolactate synthase (ALS) (Santos et al., 2014).

Devising strategies for managing $C$. bonariensis infestation in agriculture depends on the knowledge of its bioecological aspects, including growth analysis (VanGessel et al., 2009; Moreira et al., 2010a). In addition, the prevention or management of herbicideresistant weed populations requires unusual strategies using alternative herbicides, as well as information on species ecology. However, this information is frequently scarce (Moreira et al., 2010a) and is usually limited to the emergence of resistant biotypes (Vargas et al., 2007; Vidal et al., 2007) or to competitive aspects (Shrestha et al., 2010; Galon et al., 2013; Silva et al., 2014b).

Studies on the growth and development of weeds provide data on different phenological stages and growth patterns, enabling the analysis of the behavior of these plants compared with ecological factors over a growing season, as well as of their effects on the environment and especially on other plants (Marques et al., 2014; Silva et al., 2014a). The different levels of plant development have been evaluated using numerical scales. Traditionally, days are adopted as the unit of time, but this variable is often subjected to environmental interference, which is also indirectly expressed on phenology (Machado et al., 2014; Marques et al., 2014). Therefore, when there is no water stress, temperature has been regarded as the most important weather factor to predict physiological events (Gadioli et al., 2000; Lima et al., 2015).

The growing degree days (GDD) method is based on the premise that a plant needs a certain amount of energy, represented by the number of heating degrees necessary to complete each phenological phase or even the total cycle. Moreover, there is a linear relationship between temperature increase and plant growth (Gadioli et al., 2000). Therefore, mathematical models and simulation routines based on the concept of accumulated GDD may be used (Machado et al., 2014; Lima et al., 2015). Even though this concept is not different for weeds, few studies have evaluated the development of these species based on GDD (Marques et al., 2014).

The objective of this work was to evaluate the growth and development of a glyphosate-resistant population of $C$. bonariensis in different sowing dates (autumn, winter, and spring) and in two agricultural environments, based on days or thermal units.

\section{Materials and Methods}

Five independent trials were carried out in two agricultural environments, in order to evaluate the growth and development of a glyphosate-resistant biotype of $C$. bonariensis. Two experiments were performed in the municipality of Não-Me-Toque (NMT), in the state of Rio Grande do Sul (28'27'26"S, $52^{\circ} 44^{\prime} 35^{\prime \prime} \mathrm{W}$, at an altitude of $516 \mathrm{~m}$ ), and three in the municipality of Santa Cruz das Palmeiras (SCP), in the state of São Paulo $\left(21^{\circ} 49^{\prime} 07^{\prime \prime} \mathrm{S}, 4^{\circ} 16^{\prime} 06^{\prime \prime} \mathrm{W}\right.$, at an altitude of $684 \mathrm{~m}$ ), both locations in Brazil, with alternating sowing dates.

In NMT, C. bonariensis was sown on July 4, 2011, during winter, and on September 15, 2011, just before the beginning of spring. In SCP, sowings occurred on: April 13, 2011, in autumn; July 4, 2011, in winter; and September 15, 2011, just before the beginning of spring. For both agricultural environments, daily photoperiod was calculated mathematically using Cooper's formula (Cooper, 1969), based on daily solar declination and on the latitude of the locations (Figure 1).

In all the experiments, $C$. bonariensis seeds were sown directly in the experimental plots, consisting of 3.6-L pots filled with commercial substrate Bioplant Plus (Bioplanta Agrícola Ltda., Nova Ponte, MG, Brazil). Pots were irrigated twice a week with a nutrient solution containing, in ppm: $975 \mathrm{~N}, 29 \mathrm{P}, 265 \mathrm{~K}, 105$ $\mathrm{S}, 160 \mathrm{Ca}, 25 \mathrm{Mg}, 2.7 \mathrm{Fe}, 0.4 \mathrm{Zn}, 0.4 \mathrm{Mn}, 0.3 \mathrm{~B}, 0.6$ $\mathrm{Cu}$, and $4 \mathrm{Na}$. Pots were kept outside the greenhouse, where supplementary irrigation was carried out daily to ensure an adequate water supply to the plants.

The experiments were conducted in a randomized block design with ten treatments and four replicates. During the experiments, ten evaluations of growth and development were performed, which started 20 days after sowing (DAS) and were spaced at 10 days, totaling a 110-day cycle. In the first growth assessment, at $20 \mathrm{DAS}$, the least developed plants were thinned out, keeping a final density of one plant per pot. In each 
assessment, data on the development stage and total dry matter of $C$. bonariensis were recorded.

For the phenological characterization of the plants, a qualitative assessment of their development was carried out, by adapting the Biologische Bundesanstalt, Bundessortenamt und Chemische Industrie (BBCH) numeric scale proposed by Hess et al. (1997), which ranges between 0 and 100, in which, for dicotyledonous plants: 0-9 indicates germination/emergence; 10-19, leaf development; 20-29, formation of side shoots; 30-39, steam elongation; $40-49$, vegetative propagation, if present; 50-59, emergence of inflorescence; 60-69, flowering; 70-79, fruit development; 80-89, fruit and seed ripening or maturity; and 90-100, senescence. The phenological stage was defined when a given development characteristic was found in $50 \%+1$ of the total remaining plants.

The phenology evaluated in the five experiments was used to estimate the base temperature $(\mathrm{Tb})$ of C. bonariensis, according to the method adapted from Machado et al. (2014). Tb is the minimum temperature for the growth of a certain species, below which growth ceases or is greatly reduced. Therefore, accumulated thermal units (GDD) were calculated for each place and date of sowing, using arbitrary values of $\mathrm{Tb}$, namely: $5,8,10$, and $12^{\circ} \mathrm{C}$, which were estimated based on mean values from the literature. All

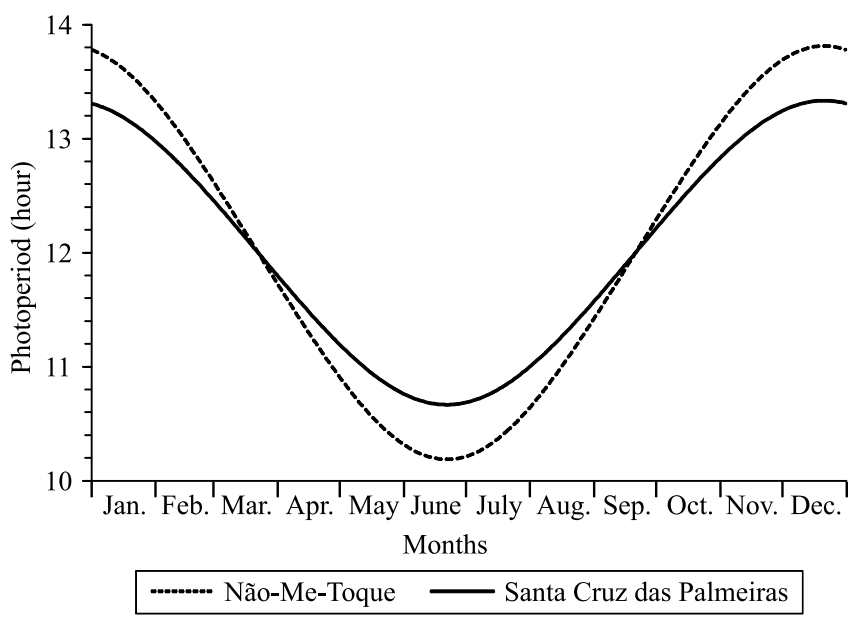

Figure 1. Hours of insolation in the agricultural environments of the municipality of Não-Me-Toque, in the state of Rio Grande do Sul, and of the municipality of Santa Cruz das Palmeiras, in the state of São Paulo, both locations in Brazil, during the different months of the year, calculated with Cooper's equation (Cooper, 1969). calculations of GDD were performed using the equation of Gilmore Junior \& Rogers (1958):

$$
\text { GDD }=((\operatorname{Tmax}+\mathrm{Tmin}) / 2)-\mathrm{Tb},
$$

in which, Tmax is the daily maximum temperature; Tmin is the daily minimum temperature; and $\mathrm{Tb}$ is the base temperature, i.e., the temperature below which the growth rate is zero. Tmax and Tmin values were obtained from weather stations installed in the municipalities of NMT and SCP, and Tb was obtained mathematically.

The accumulated phenology of $C$. bonariensis was then fitted to GDD through the linear regression model: $\mathrm{y}=\mathrm{ax}$, according to Machado et al. (2014), in which y is the estimate of the development of $C$. bonariensis according to the phenological scale (Hess et al., 1997); $\mathrm{x}$ are the accumulated heating units; and $\mathrm{a}$ is a parameter of the model.

After fitting the accumulated phenology to the linear model for the four arbitrary temperatures, the following dispersion parameters were calculated: coefficient of determination $\left(\mathrm{R}^{2}\right)$, mean squared residue $\left(\mathrm{MS}_{\mathrm{res}}\right)$, and the F-test of the model. The relationship between arbitrary temperatures and dispersion parameters was fitted to quadratic equations in order to obtain the lowest point of variation, making the first derivative of the equation equal to zero. The mean of the minimum or maximum points of the regressions corresponded to the optimal $\mathrm{Tb}$ for the species.

After obtaining species $\mathrm{Tb}$, the accumulated phenology was fitted again to GDD and to DAS. Furthermore, the individual developmental conditions were fitted to the same equation, i.e., $y=a x$. To compare the phenology of the species regardless of the experiments, the overlapping confidence interval was analyzed (Carvalho \& Christoffoleti, 2007). In the event of an overlap, equations were considered as equal, whereas, in the absence of an overlap, they were considered different.

For evaluations of dry mass, experiments were assessed separately. For this purpose, four plots (replicates) were randomly sampled by the destructive sampling method. Plants were washed in running water to remove the remaining substrate from the roots; then, the material was dried at $70^{\circ} \mathrm{C}$ for 72 hours. After drying, total dry mass (grams per plant) was measured.

Total dry mass was subjected to the F-test on the analysis of variance, followed by the application of nonlinear logistic regression in order to model data to 
equations. Data were fitted based on days (DAS) or on thermal units (GDD), adopting the model proposed by Streibig (1988): $y=a /\left(1+(x / b)^{c}\right)$, in which $y$ is the response variable of interest; $x$ is the timescale (DAS or GDD); and a, b, and c are the parameters estimated for the equation $-\mathrm{a}$ is the existing range between the maximum and minimum points of the variable; $b$ is the timescale value required for the occurrence of $50 \%$ of the response of the variable; and $\mathrm{c}$ is the slope of the curve around $b$.

\section{Results and Discussion}

For both agricultural environments and the different sowing dates, the $\mathrm{R}^{2}$ of the equations was greater than $85 \%$ and the best fit for the $\mathrm{Tb}$ values was found between 8 and $10^{\circ} \mathrm{C}$ (Figure 2). Considering the three measures of dispersion, second-degree regressions were calculated, whose minimum $\left(\mathrm{MS}_{\mathrm{res}}\right)$ or maximum
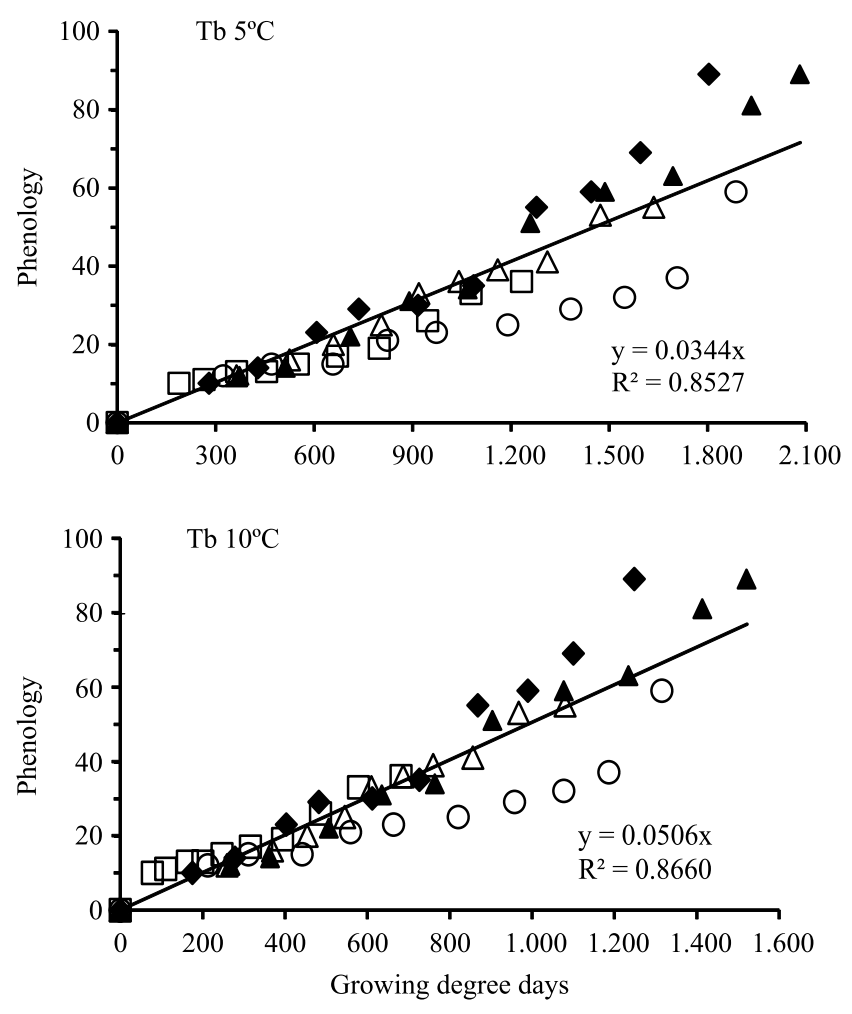

口NMT - July $\bullet$ NMT - September $\Delta$ SCP - April OSCP - July $\Delta$ SCP - September

Figure 2. Accumulated phenological development of Conyza bonariensis, according to the scale of Hess et al. (1997), when sown in the agricultural environments of the municipality of Não-Me-Toque (NMT), in the state of Rio Grande do Sul, and of the municipality of Santa Cruz das Palmeiras (SCP), in the state of São Paulo, both locations in Brazil, in different seasons, fitted to growing degree days, calculated with base temperatures of $5,8,10$, and $12^{\circ} \mathrm{C}$. Tb, base temperature.

Pesq. agropec. bras., Brasília, v.52, n.1, p.45-53, jan. 2017

DOI: $10.1590 / \mathrm{S} 0100-204 \mathrm{X} 2017000100006$
$\left(\mathrm{R}^{2}\right.$ and $\left.\mathrm{F}\right)$ point defines the ideal $\mathrm{Tb}$ for the species. Therefore, for $C$. bonariensis, the mean of the $\mathrm{Tb}$ optimum values was $8.4^{\circ} \mathrm{C}$ (Table 1 ).

Also working with $C$. bonariensis, Wu et al. (2007) found $\mathrm{Tb}$ of $4.2^{\circ} \mathrm{C}$, whereas Navea (2013) observed $\mathrm{Tb}$ of $10.6^{\circ} \mathrm{C}$. Using different methods, Steinmaus et al. (2000) obtained average $\mathrm{Tb}$ of 8.3 and $13.8^{\circ} \mathrm{C}$, respectively, for winter and summer annual weeds, among which $C$. canadensis was considered as a winter or a summer species, with $\mathrm{Tb}$ ranging from 11.1 to $14.1^{\circ} \mathrm{C}$.

For other weed species, the $\mathrm{Tb}$ found was of: around $10^{\circ} \mathrm{C}$ for honeyweed (Leonurus sibiricus L.), by Silva et al. (2014a); $12^{\circ} \mathrm{C}$ for southern sandbur (Cenchrus echinatus L.), by Machado et al. (2014); $12^{\circ} \mathrm{C}$ for purple nutsedge (Cyperus rotundus L.), by Lima et al. (2015); and 10 or $15^{\circ} \mathrm{C}$ for sourgrass [Digitaria insularis (L.) Mez ex Ekman], by Marques et al. (2014). In this
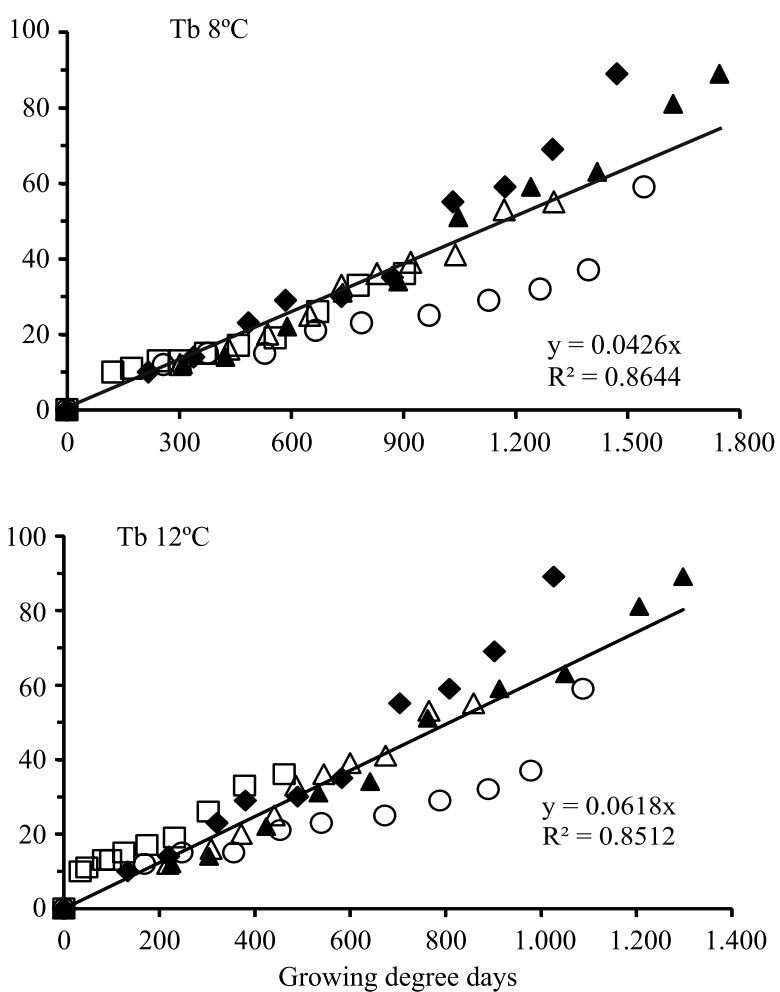
context, in general, species with better adaptation to cold climate, with $\mathrm{C} 3$ photosynthetic cycle and smaller size, have $\mathrm{Tb}$ below $10^{\circ} \mathrm{C}$. Moreover, the $\mathrm{Tb}$ of tropical species with $\mathrm{C} 4$ photosynthetic cycle, particularly of plants of the Poaceae family, is higher than $10^{\circ} \mathrm{C}$ and ranges up to $15^{\circ} \mathrm{C}$. Therefore, for Brazilian tropical conditions, for the distribution and occurrence of $C$. bonariensis, and for the characterization of the species as an annual one (Lazaroto et al., 2008) with C3 photosynthetic cycle, $\mathrm{Tb}=8.4^{\circ} \mathrm{C}$ is considered as an adequate parameter, which was used for the remaining analyses in the present study.

Comparatively, using $\mathrm{Tb}=8.4^{\circ} \mathrm{C}$ for $C$ bonariensis was much more efficient in standardizing species development than days as the unit of time (Figure 3). Considering the axis DAS, a greater dispersion of points was evident, with $\mathrm{R}^{2}$ of 0.70 . The use of thermal units promoted greater grouping of phenology points, especially at the initial period of species development, up to $900 \mathrm{GDD}$, when management measures are recommended.

Besides being more efficient than days for the prediction of $C$. bonariensis development, thermal units also allowed differentiating between agricultural environments and sowing dates (Table 2). In this analysis, the higher the value of parameter a of the model $(y=a x)$, the faster plant development is in a given condition. The obtained results showed that the speed development of $C$. bonariensis was: faster, for sowing in September, in spring, in the municipality of NMT $(\mathrm{a}=0.0538)$, with no difference for the municipality of SCP in the same month $(\mathrm{a}=0.0484)$; intermediary, for sowing in July, in winter, in NMT $(\mathrm{a}=0.0426)$, and in April, in autumn $(\mathrm{a}=0.0436)$, in $\mathrm{SCP}$; and slower, for sowing in July, in winter, in SCP $(\mathrm{a}=0.0307)$.

Table 1. Estimators of variability for fitting the phenological development of Conyza bonariensis using different base temperatures, second-degree polynomial regression, minimum or maximum point of the curve $\left(\mathrm{P}_{\min / \max }\right)$, and final mean.

\begin{tabular}{|c|c|c|c|c|}
\hline \multirow[t]{2}{*}{ Estimator } & \multicolumn{4}{|c|}{ Base temperature } \\
\hline & $5^{\circ} \mathrm{C}$ & $8^{\circ} \mathrm{C}$ & $10^{\circ} \mathrm{C}$ & $12^{\circ} \mathrm{C}$ \\
\hline Coefficient of determination $\left(\mathrm{R}^{2}\right)$ & 0.8527 & 0.8644 & 0.8660 & 0.8512 \\
\hline Mean squared residue & 72.565 & 66.804 & 65.975 & 73.274 \\
\hline$\underline{F_{\text {model }}}$ & $1002.946^{* *}$ & $1094.105^{* *}$ & $1108.529 * *$ & $992.732 * *$ \\
\hline Estimator & \multicolumn{2}{|c|}{ Regression } & $\mathrm{R}^{2}$ & $\mathrm{P}_{\min / \max }$ \\
\hline $\mathrm{R}^{2}$ & \multicolumn{2}{|c|}{$y=-0.0012 x^{2}+0.0199 x+0.7821$} & 0.9495 & 8.291 \\
\hline Mean squared residue & \multicolumn{2}{|c|}{$y=0.5777 x^{2}-9.8056 x+107.36$} & 0.9481 & 8.497 \\
\hline $\mathrm{F}_{\text {model }}$ & \multicolumn{2}{|c|}{$y=-9.1385 x^{2}+155.3 x+451.52$} & 0.9452 & 8.480 \\
\hline Final mean & & & & $8.4^{\circ} \mathrm{C}$ \\
\hline
\end{tabular}

**Significant by the F-test, at $1 \%$ probability.
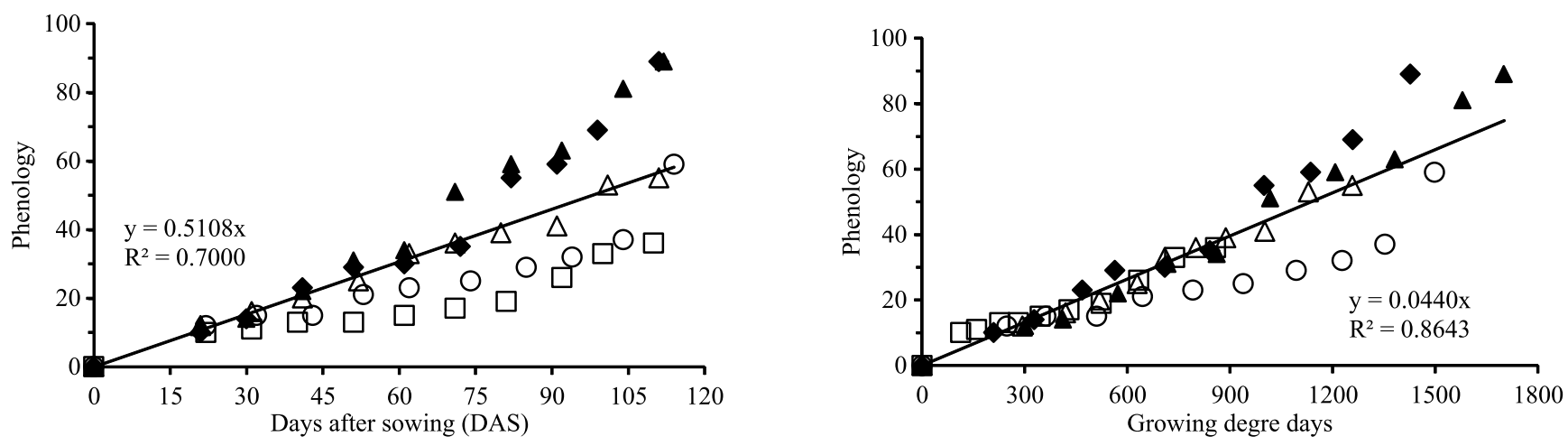

口NMT - July •NMT - September $\Delta$ SCP - April OSCP - July $\Delta$ SCP - September

Figure 3. Accumulated phenological development of Conyza bonariensis, according to the scale of Hess et al. (1997), when sown in the agricultural environments of the municipality of Não-Me-Toque (NMT), in the state of Rio Grande do Sul, and of the municipality of Santa Cruz das Palmeiras (SCP), in the state of São Paulo, both locations in Brazil, in different seasons, fitted to days after sowing or growing degree days $\left(\mathrm{Tb}=8.4^{\circ} \mathrm{C}\right) . \mathrm{Tb}$, base temperature. 
Table 2. Coefficient of determination $\left(\mathrm{R}^{2}\right)$, F-test applied to the model $(\mathrm{y}=\mathrm{ax})$, and confidence interval of parameter a relative to the fits of the phenological development of Conyza bonariensis to accumulated thermal units $\left(\mathrm{Tb}=8.4{ }^{\circ} \mathrm{C}\right)$, considering different agricultural environments and sowing dates (months).

\begin{tabular}{lccccccc}
\hline $\begin{array}{l}\text { Agricultural } \\
\text { environment }\end{array}$ & Month & $\mathrm{R}^{2}$ & $\mathrm{~F}_{\text {model }}$ & $\mathrm{a}$ & \multicolumn{3}{c}{ Confidence interval (5\%) $)^{(1)}$} \\
\hline NMT & & & & $\mathrm{P}_{\min }$ & $\mathrm{P}_{\max }$ & Comparison \\
NMT & July & 0.9346 & $609.835^{* *}$ & 0.0426 & 0.0388 & 0.0465 & $\mathrm{~B}$ \\
SCP & September & 0.9529 & $642.791^{* *}$ & 0.0538 & 0.0491 & 0.0585 & $\mathrm{~A}$ \\
SCP & April & 0.9844 & $2791.877^{* *}$ & 0.0436 & 0.0418 & 0.0454 & $\mathrm{~B}$ \\
SCP & July & 0.8755 & $291.183^{* *}$ & 0.0307 & 0.0266 & 0.0346 & $\mathrm{C}$ \\
\hline
\end{tabular}

(1)NMT, municipality of Não-Me-Toque, in the state of Rio Grande do Sul, Brazil; and SCP, municipality of Santa Cruz das Palmeiras, in the state of São Paulo, Brazil. (2) $\mathrm{P}_{\min }$ and $\mathrm{P}_{\max }$, minimum or maximum point of the curve. ${ }^{*}$ Significant by the $\mathrm{F}$-test, at $1 \%$ probability.
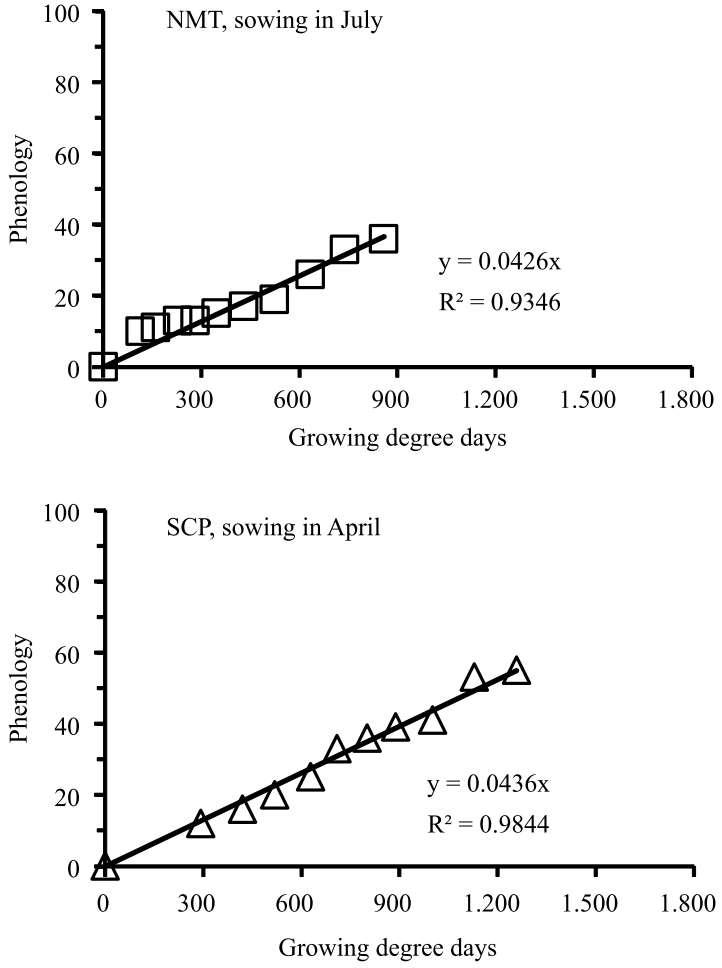
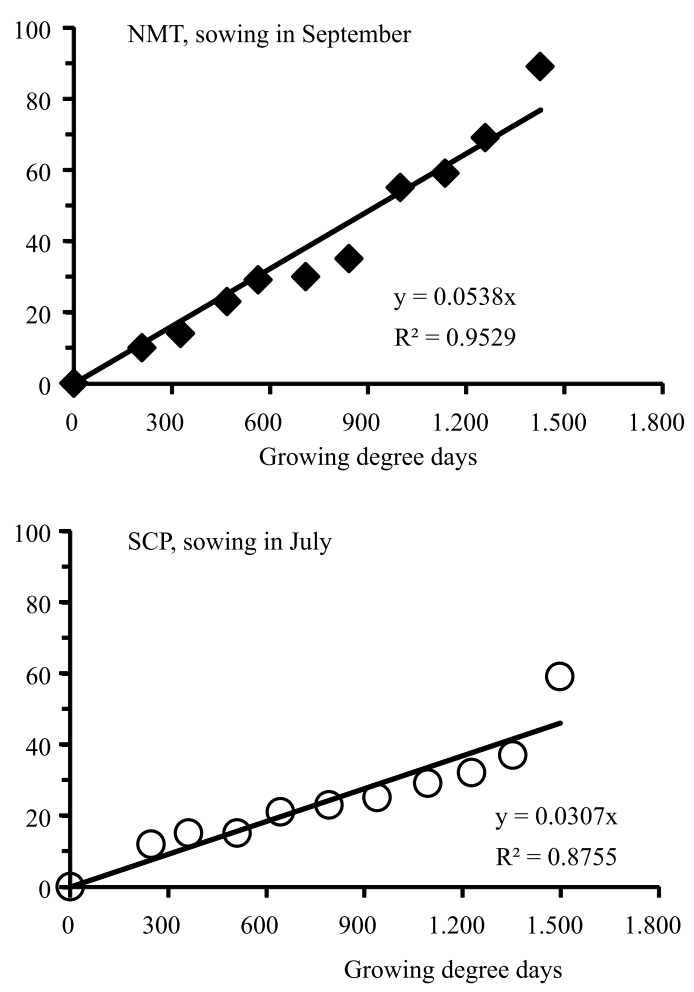

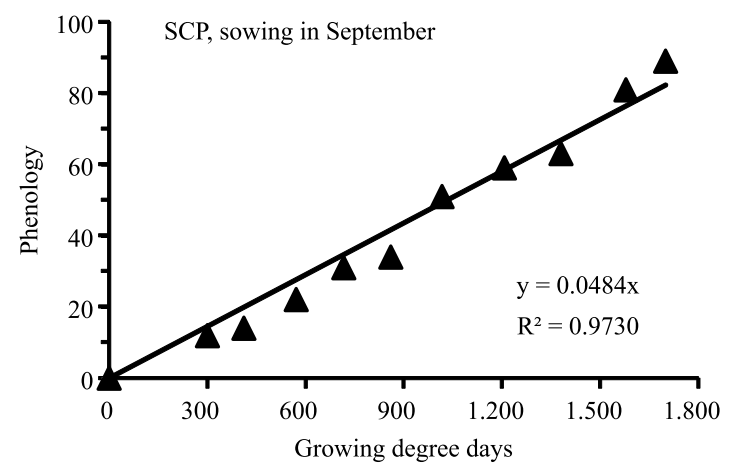

Figure 4. Phenological development of Conyza bonariensis, according to the scale of Hess et al. (1997), when sown in the agricultural environments of the municipality of Não-Me-Toque (NMT), in the state of Rio Grande do Sul, and of the municipality of Santa Cruz das Palmeiras (SCP), in the state of São Paulo, both locations in Brazil, in different seasons of the year, fitted to growing degree days $\left(\mathrm{Tb}=8.4{ }^{\circ} \mathrm{C}\right)$. $\mathrm{Tb}$, base temperature. 
However, in all regions, the development of the species was considered slow (Figure 4), with significant environmental effect on flowering, possibly due to the photoperiod. No flowering was observed with sowing in a decreasing photoperiod, in April, in SCP, or in an increasing photoperiod, in July, in NMT; however, flowering occurred in the last sampling in SCP. It should be noted that, when sowing was performed just before the beginning of spring, in September, with higher temperature and increased photoperiod, flowering of the species was quick in both locations, with approximately 1,200 GDD.

These results are in agreement with those of Vargas et al. (2007) and Lazaroto et al. (2008), who found that, although this species may emerge throughout the year, its peak occurs during spring and its cycle ends in the summer; therefore, it can be characterized as a winter and summer plant. This shows that there is a clear effect of photoperiod on species flowering. Floral induction was much more severe when sowings were carried out in spring - with rapid plant development and the emergence of buds and flowers (Figure 4) and was also clearly more intense with an increasing photoperiod, equal to or above 12 hours of sunlight (Figure 1). In this environment, which is typical of spring, the development of the species was intense, with a high value for parameter a of the line (Table 2) and with early flowering.

Table 3. Scale, agricultural environments, and month of development of the experiment, as well as coefficient of determination $\left(\mathrm{R}^{2}\right)$, F-test of the model ${ }^{(1)}$, and parameters $\mathrm{a}, \mathrm{b}$, and $\mathrm{c}$ of the logistic equation used to fit the total dry mass (grams per plant) of Conyza bonariensis.

\begin{tabular}{|c|c|c|c|c|c|c|c|}
\hline \multirow[t]{2}{*}{ Scale } & \multirow[t]{2}{*}{ Location $^{(2)}$} & \multirow[t]{2}{*}{ Month } & \multirow[t]{2}{*}{$\mathrm{F}$} & \multicolumn{3}{|c|}{ Parameters of the model } & \multirow[t]{2}{*}{$\mathrm{R}^{2}$} \\
\hline & & & & $\mathrm{a}$ & $\mathrm{b}$ & $\mathrm{c}$ & \\
\hline \multirow{5}{*}{$\begin{array}{l}\text { Days after } \\
\text { sowing }\end{array}$} & NMT & July & $634.341 * *$ & 10.812 & 95.537 & -66.959 & 0.993 \\
\hline & NMT & September & $138.224^{* *}$ & 5.160 & 74.770 & -10.694 & 0.972 \\
\hline & SCP & April & $202.074 * *$ & 40.961 & 79.877 & -6.582 & 0.980 \\
\hline & SCP & July & $1212.710^{* *}$ & 22.114 & 104.290 & -21.933 & 0.996 \\
\hline & SCP & September & $201.311^{* *}$ & 23.093 & 98.844 & -3.779 & 0.980 \\
\hline \multirow{5}{*}{$\begin{array}{l}\text { Degree days } \\
\mathrm{Tb}^{(3)}=8.4^{\circ} \mathrm{C}\end{array}$} & NMT & July & $862.642 * *$ & 10.770 & 674.510 & -37.277 & 0.995 \\
\hline & NMT & September & $147.879^{* *}$ & 5.138 & 887.027 & -8.819 & 0.974 \\
\hline & SCP & April & $190.993 * *$ & 38.696 & 874.970 & -7.784 & 0.979 \\
\hline & SCP & July & $1135.010 * *$ & 21.125 & 1351.538 & -23.238 & 0.996 \\
\hline & SCP & September & $190.369 * *$ & 24.100 & 1527.922 & -3.310 & 0.979 \\
\hline
\end{tabular}

${ }^{(1)} \mathrm{y}=\mathrm{a} /\left(1+(\mathrm{x} / \mathrm{b})^{\mathrm{c}}\right) .{ }^{(2)} \mathrm{NMT}$, municipality of Não-Me-Toque, in the state of Rio Grande do Sul, Brazil; and SCP, municipality of Santa Cruz das Palmeiras, in the state of São Paulo, Brazil. ${ }^{(3)} \mathrm{Tb}$, base temperature. ${ }^{* *}$ Significant by the F-test, at $1 \%$ probability.
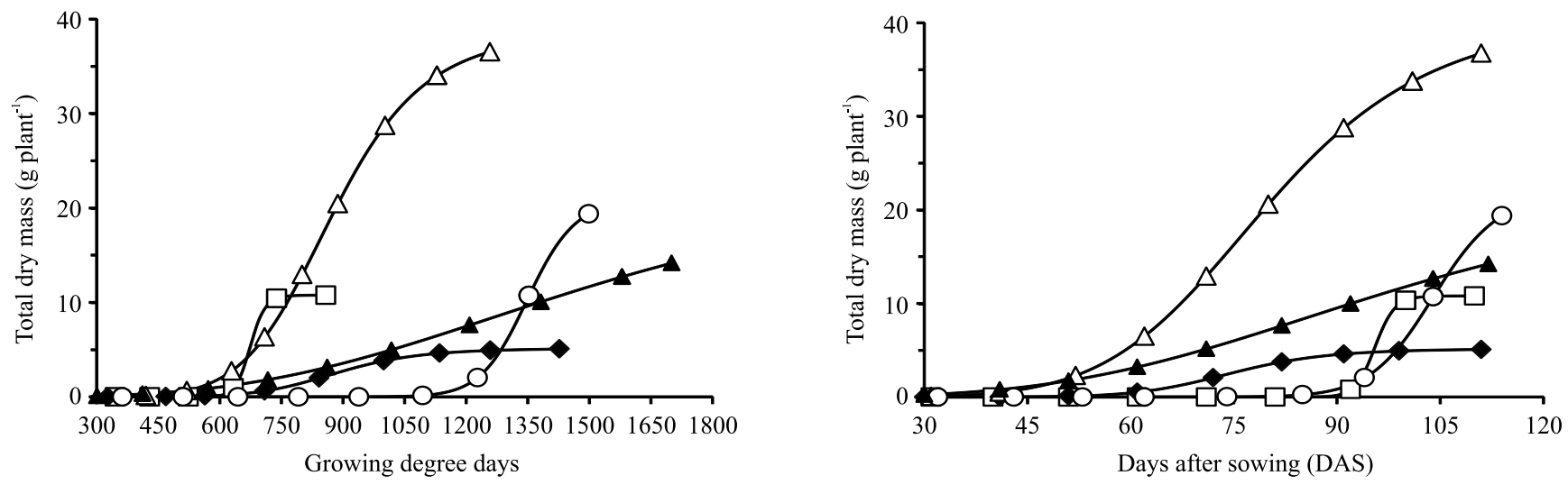

$\neg \square$ NMT July $\multimap$ NMT September $\backsim$ SCP April $\multimap-$ SCP July $\multimap$ SCP September

Figure 5. Total dry matter accumulation by Conyza bonariensis plants when sown in the agricultural environments of the municipality of Não-Me-Toque (NMT), in the state of Rio Grande do Sul, and of the municipality of Santa Cruz das Palmeiras (SCP), in the state of São Paulo, both locations in Brazil, in different seasons of the year, fitted to days or growing degree days $\left(\mathrm{Tb}=8.4^{\circ} \mathrm{C}\right)$. $\mathrm{Tb}$, base temperature. 
Agricultural environments and sowing dates also affected species growth (mass accumulation), considering days or GDD as the unit of time (Table 3). Noticeably, the largest species mass accumulation occurred for sowing in April, in SCP, with total dry mass above $35 \mathrm{~g}$ per plant (Figure 5). There is a clear behavioral pattern for the species: the earlier the induction of flowering, the lower is the total mass accumulation (Figures 4 and 5). Moreira et al. (2010a) observed that maximum total dry matter did not reach $6 \mathrm{~g}$ per plant with sowing in January, which may have caused early floral induction due to days with long insolation.

Marques et al. (2014) recognized that, in biological terms, growth is different from development. While growth may be understood as an irreversible increase in mass and volume, development refers to alternating successive physiological stages, which are expressed in plant phenology. There is, therefore, a physiological binomial growth-development, and, in the case of C. bonariensis, investing in a process can delay the other one, and vice versa. In a cold environment with decreasing photoperiod (winter), the species can accumulate mass, but develops slowly. In addition, when increased temperature and photoperiod (spring) take place, mass accumulation is lower, but induction of flowering is evident (Figures 1, 4, and 5). These considerations have a valuable practical application because, through mathematical models, it is possible to estimate the duration of the initial developmental stages of the species, when it is more sensitive to chemical control.

\section{Conclusions}

1. The best adjustment for Conyza bonariensis phenological development is reached at the base temperature of $8.4^{\circ} \mathrm{C}$.

2. The phenological development of the species C. bonariensis is affected by sowing date and agricultural environments.

3. In cold environments, in autumn, with a decreasing photoperiod, C. bonariensis is still able to accumulate dry mass, but without floral induction.

4. In spring conditions and with increasing photoperiod, dry mass accumulation of $C$. bonariensis is lower, although phenological development is faster, with significant floral induction.

\section{References}

CARVALHO, S.J.P.; CHRISTOFFOLETI, P.J. Estimativa da área foliar de cinco espécies do gênero Amaranthus usando dimensões lineares do limbo foliar. Planta Daninha, v.25, p.317-324, 2007. DOI: $10.1590 / \mathrm{S} 0100-83582007000200011$.

COOPER, P.I. The absorption of radiation in solar stills. Solar Energy, v.12, p.333-346, 1969. DOI: 10.1016/0038092X(69)90047-4.

DAUER, J.T.; MORTENSEN, D.A.; HUMSTON, R. Controlled experiments to predict horseweed (Conyza canadensis) dispersal distances. Weed Science, v.54, p.484-489, 2006. DOI: 10.1614/ WS-05-017R3.1.

GADIOLI, J.L.; DOURADO-NETO, D.; GARCÍA Y GARCÍA, A.; BASANTA, M. del V. Temperatura do ar, rendimento de grãos de milho e caracterização fenológica associada à soma calórica. Scientia Agricola, v.57, p.377-383, 2000. DOI: 10.1590/S010390162000000300001.

GALON, L.; FERREIRA, E.A.; CONCENÇO, G.; SILVA, A.A.; SILVA, D.V.; SILVA, A.F.; ASPIAZÚ, I.; VARGAS, L. Características fisiológicas de biótipos de Conyza bonariensis resistentes ao glyphosate cultivados sob competição. Planta Daninha, v.31, p.859-866, 2013. DOI: 10.1590/S010083582013000400012 .

GILMORE JUNIOR, E.C.; ROGERS, J.S. Heat units as a method of measuring maturity in corn. Agronomy Journal, v.50, p.611615, 1958. DOI: 10.2134/agronj1958.00021962005000100014x.

HESS, M.; BARRALIS, G.; BLEIHOLDER, H.; BUHR, L.; EGGERS, TH.; HACK, H.; STAUSS, R. Use of the extended $\mathrm{BBCH}$ scale - general for descriptions of the growth stages of mono- and dicotyledonous weed species. Weed Research, v.37, p.433-441, 1997. DOI: 10.1046/j.1365-3180.1997.d01-70.x.

LAMEGO, F.P.; VIDAL, R.A. Resistência ao glyphosate em biótipos de Conyza bonariensis e Conyza canadensis no estado do Rio Grande do Sul, Brasil. Planta Daninha, v.26, p.467-471, 2008. DOI: $10.1590 / \mathrm{S} 0100-83582008000200024$.

LAZAROTO, C.A.; FLECK, N.G.; VIDAL, R.A. Biologia e ecofisiologia de buva (Conyza bonariensis e Conyza canadensis). Ciência Rural, v.38, p.852-860, 2008. DOI: 10.1590/S010384782008000300045.

LIMA, R.S.O.; MACHADO, E.C.R.; SILVA, A.P.P.; MARQUES, B.S.; GONÇALVES, M.F.; CARVALHO, S.J.P. Growth and development of purple nutsedge based on days or thermal units. Planta Daninha, v.33, p.165-173, 2015. DOI: 10.1590/010083582015000200001 .

MACHADO, E.C.R.; LIMA, R.S.O.; SILVA, A.P.P.; MARQUES, B.S.; GONÇALVES, M.F.; CARVALHO, S.J.P. Initial growth and development of southern sandbur based on thermal units. Planta Daninha, v.32, p.335-343, 2014. DOI: 10.1590/S010083582014000200011.

MARQUES, B.S.; SILVA, A.P.P.; LIMA, R.S.O.; MACHADO, E.C.R.; GONÇALVES, M.F.; CARVALHO, S.J.P. Growth and development of sourgrass based on days or thermal units. 
Planta Daninha, v.32, p.483-490, 2014. DOI: 10.1590/S010083582014000300003.

MOREIRA, M.S.; MELO, M.S.C. de; CARVALHO, S.J.P. de; CHRISTOFFOLETI, P.J. Crescimento diferencial de biótipos de Conyza spp. resistente e suscetível ao herbicida glifosato. Bragantia, v.69, p.591-598, 2010a. DOI: 10.1590/S000687052010000300010.

MOREIRA, M.S.; MELO, M.S.C.; CARVALHO, S.J.P.; NICOLAI, M.; CHRISTOFFOLETI, P.J. Herbicidas alternativos para controle de biótipos de Conyza bonariensis e C. canadensis resistentes ao glyphosate. Planta Daninha, v.28, p.167-175, 2010b. DOI: $10.1590 / \mathrm{S} 0100-83582010000100020$.

MOREIRA, M.S.; NICOLAI, M.; CARVALHO, S.J.P.; CHRISTOFFOLETI, P.J. Resistência de Conyza canadensis e C. bonariensis ao herbicida glyphosate. Planta Daninha, v.25, p.157-164, 2007. DOI: 10.1590/S0100-83582007000100017.

NAVEA, C.L.Z. Demografía y dinámica poblacional de Conyza bonariensis (L.) Cronq. 2013. 97 p. Tese (Doutorado em Ciências) - Universidade de Córdoba, Córdoba.

SANTOS, G.; FRANCISCHINI, A.C.; BLAINSKI, E.; GEMELLI, A.; MACHADO, M.F.P.S. Aspectos da biologia e da germinação da buva. In: CONSTANTIN, J.; OLIVEIRA JUNIOR, R.S. de; OLIVEIRA NETO, A.M. de (Ed.). Buva: fundamentos e recomendações para manejo. Curitiba: Omnipax, 2013. p.11-26. DOI: 10.7436/2013.bfrm.03.

SANTOS, G.; OLIVEIRA JR., R.S.; CONSTANTIN, J.; FRANCISCHINI, A.C.; OSIPE, J.B. Multiple resistance of Conyza sumatrensis to chlorimuron-ethyl and to glyphosate. Planta Daninha, v.32, p.409-416, 2014. DOI: 10.1590/S010083582014000200019 .

SHRESTHA, A.; HANSON, B.D.; FIDELIBUS, M.W.; ALCORTA, M. Growth, phenology, and intraspecific competition between glyphosate-resistant and glyphosate-susceptible horseweeds (Conyza canadensis) in the San Joaquin Valley of California. Weed Science, v.58, p.147-153, 2010. DOI: 10.1614/ WS-D-09-00022.1.
SILVA, A.P.P.; MARQUES, B.S.; LIMA, R.S.O.; MACHADO, E.C.R.; GONÇALVES, M.F.; CARVALHO, S.J.P. Growth and development of honey weed based on days or thermal units. Planta Daninha, v.32, p.81-89, 2014a. DOI: 10.1590/S010083582014000100009 .

SILVA, D.R.O. da; VARGAS, L.; AGOSTINETTO, D.; MARIANI, F. Glyphosate-resistant hairy fleabane competition in $\mathrm{RR}^{\circledR}$ soybean. Bragantia, v.73, p.451-457, 2014b. DOI: $10.1590 / 1678-4499.0200$.

STEINMAUS, S.J.; PRATHER, T.S.; HOLT, J.S. Estimation of base temperatures for nine weed species. Journal of Experimental Botany, v.51, p.275-286, 2000. DOI: 10.1093/jexbot/51.343.275.

STREIBIG, J.C. Herbicide bioassay. Weed Research, v.28, p.479484, 1988. DOI: 10.1111/j.1365-3180.1988.tb00831.x.

VANGESSEL, M.J.; SCOTT, B.A.; JOHNSON, Q.R.; WHITEHANSEN, S.E. Influence of glyphosate-resistant horseweed (Conyza canadensis) growth stage on response to glyphosate applications. Weed Technology, v.23, p.49-53, 2009. DOI: 10.1614/WT-07-108.1.

VARGAS, L.; BIANCHI, M.A.; RIZZARDI, M.A.; AGostinetTO, D.; DAL MAGRO, T. Buva (Conyza bonariensis) resistente ao glyphosate na região Sul do Brasil. Planta Daninha, v.25, p.573-578, 2007. DOI: 10.1590/S010083582007000300017.

VIDAL, R.A.; KALSING, A.; GOULART, I.C.G.R.; LAMEGO, F.P.; CHRISTOFFOLETI, P.J. Impacto da temperatura, irradiância e profundidade das sementes na emergência e germinação de Conyza bonariensis e Conyza canadensis resistentes ao glyphosate. Planta Daninha, v.25, p.309-315, 2007. DOI: 10.1590/ S0100-83582007000200010.

WU, H.; WALKER, S.; ROLLIN, M.J.; TAN, D.K.Y.; ROBINSON, G.; WERTH, J. Germination, persistence and emergence of flaxleaf fleabane (Conyza bonariensis [L.] Cronquist). Weed Biology and Management, v.7, p.192-199, 2007. DOI: 10.1111/j.14456664.2007.00256.x.

Received on March 11, 2016 and accepted on August 1, 2016 